\title{
Pengembangan Instrumen Temperamen (Carita) Dalam Perspektif Buddhis Berdasar Kitab Visuddhimagga (Studi Pada Mahasiswa Perguruan Tingggi Keagamaan Buddha Indonesia)
}

\author{
Kemanya Karbono
}

\author{
STAB Negeri Sriwijaya Tangerang Banten \\ email:akarbono@yahoo.com
}

\begin{abstract}
Abstrak
Penelitian ini bertujuan untuk mengembangkan instrumen alat ukur klasifikasi temperamen (carita) yang valid dan reliabel. Proses pengujian melalui dua tahap, yakni secara teoritis dan empiris. Pengujian empiris melibatkan 103 mahasiswa dari 6 Perguruan Tinggi Keagamaan Buddha di Indonesia. Teknik pengambilan sampling menggunakan metode simple random sampling. Validasi empiris dan pengukuran model dikonfirmasi menggunakan Confirmatory Factor Analysis (CFA) dengan bantuan software Lisrel 8.80. Reliabilitas instrumen diukur dengan Construct Reliability (CR) dan Varian Extraced (VE). Hasil penelitian menunjukan bahwa instrumen temperamen (carita) terdiri dari enam dimensi, yaitu: (1) Ragacarita (serakah); (2) Dosacarita (benci); (3) Mohacarita (bodoh) dengan; (4) Saddhacarita (yakin); (5) Buddhicarita (pandai); (6) Vitakkacarita (spekulatif).
\end{abstract}

Kata Kunci: pengembangan instrumen, temperamen (carita), visuddhimagga

\section{Development Of Temperamen Instruments (Carita) In Buddhis Perspective Based On The Visuddhimagga (Study On Students Of Religious Higher Education Buddha Indonesia)}

\begin{abstract}
This study aims to develop a valid and reliable instrument of temperament (carita). The testing process through two stages, namely theoretically and empirically. The empirical test involved 103 students from 6 Buddhist Religious Universities in Indonesia. Sampling technique using simple random sampling method. Empirical validation and model measurements were confirmed using Confirmatory Factor Analysis (CFA) with the help of Lisrel 8.80 software. Instrument reliability is measured by Construct Reliability (CR) and Varian Extraced (VE). The results showed that the instrument of temperament (carita) consists of six dimensions, namely: (1) Ragacarita (greedy); (2) Dosacarita (hate); (3) Mohacarita (stupid) with; (4) Saddhacarita (sure); (5) Buddhicarita (clever); (6) Vitakkacarita (speculativ
\end{abstract}

Keywords: development of instruments, temperament (carita), visuddhimagga

\section{Pendahuluan}

Manusia dilahirkan berbeda adalah ketentuan hukum alam dan menjadi suatu realitas yang tak terbantahkan. Dari sekian banyak perbedaan, temperamen menjadi salah satu yang menjadi perhatian. Hal tersebut didasarkan atas asumsi bahwa temperamen cenderung menentukan cara berpikir, bertindak, dan merasa. Dengan mengenali temperamen seseorang, maka dapat diperkirakan bagaimana reaksi orang tersebut jika diha- dapkan pada situasi tertentu. Usaha untuk memahami manusia dengan menggolongkan temperamen ke dalam tipe-tipe tertentu sudah dilakukan sejak dulu kala, hal tersebut dianggap sebagai cara yang efektif untuk lebih memahami karakteristik manusia. Salah satu contoh ahli yang familiar dalam pengklasifikasian temperamen adalah Hippocrates, ia membaginya ke dalam empat kelompok berdasarkan segi kejiwaan yaitu: kholeris, melankolis, phlegmatis, dan sanguis. 
Dimasa kontemporer penggolongan temperamen banyak dimanfaatkan dalam berbagai bidang. Dunia pendidikan misalnya, menggunakannya sebagai instrumen untuk memahami peserta didik sehingga pendidik mampu memperlakukan siswa sesuai keadaannya dengan memberikan treatmen yang tepat sehingga kemajuan dalam belajar tercapai. contoh lain adalah bidang kesehatan mental atau psikologi. Ketika memberikan konseling, seorang psikolog akan meresepkan saran untuk memecahkan masalah mental pasiennya dengan menyesuaikan karakteristik pribadinya.

Dalam keagamaan Buddha, penggolongan temperamen sudah digunakan oleh Sang Buddha lebih dari 2500 tahun yang lalu. Teori buddhis tentang temperamen muncul dalam teks Visuddhimagga. Teks ini menyajikan klasifikasi temperamen sebagai alat yang berguna untuk menyesuaikan intervensi bagi individu tertentu untuk mencapai manfaat maksimal dalam kehidupan spiritual, menentukan gaya hidup berkaitan dengan tempat tinggal, pakaian, dan makanan. Namun yang paling menonjol adalah digunakan untuk menentukan objek meditasi agar seseorang sukses dalam menjalankan praktik meditasi. Manfaat terakhir masih banyak digunakan diberbagai tempat retreat meditasi, hanya saja penentuan subjek meditasi berdasar jenis tempramen diputuskan oleh pembimbing meditasi senior. Penentuan tersebut didasarkan pada pernyataan bahwa seorang guru yang telah mencapai penembusan batin akan mengetahui temperamen dan objek meditasi yang sesuai, orang yang belum mencapai penembusan harus menanyai muridnya (Buddhaghosa, 1996: 68).

Istilah kepribadian dan temperamen seringkali digunakan untuk merujuk perbedaan perilaku individu yang relatif stabil. Meskipun batasan antara kepribadian dan temperamen kabur, makna kedua konsep tersebut dapat dibedakan. Wundt (1903) mendefinisikan temperamen sebagai reaktivitas emosional dari kebiasaan individu. Sedangkan McDougall (1923) lebih menekankan faktor fisiologis dan biokimia, ia menyatakan bahwa reaksi psikomotor khas seorang in- dividu sebagai milik temperamen (Angleitner, Alois \& Rainer Riemann, 1991: 192). Dalam pandangan Alport (1937) temperamen didefinisikan sebagai gejala karaktersitik dari sifat emosi individu, termasuk kerentanan untuk stimulasi emosional, kekuatan dan kecepatan bereaksi, kualitas kekuatan suasana hati secara fluktuasi dan intensitas mood, serta bergantung pada faktor konstitusional, yang karenanya terutama berasal dari keturunan. Dalam publikasi yang lebih baru, Buss dan Poley mendefinisikan temperamen sebagai karaktersitik yang sebagian besar adalah cara gaya berperilaku dalam situasi sosial (Angleitner, Alois \& Rainer Riemann, 1991: 195). Dari berbagai definisi temperamen yang dikemukakan oleh para ahli, dapat disintesiskan bahwa temperamen adalah karaketrsitik sifat emosi seseorang yang relatif tetap (biasanya faktor genetik) terdapat di dalam kepribadian dan watak dan berkaitan erat dengan determinan biologik atau fisiologik yang dapat mempengaruhi perbuatan, perasaan, dan pikiran.

Dalam perspektif buddhis, temperamen dikenal dengan nama carita. Istilah tersebut berasal dari Bahasa Pali yang merupakan kombinasi dari kata depan 'car' dan akhiran 'ta'. Menurut Pali English Dictionary, carita diartikan sebagai perilaku, temperamen, sifat atau karakter seseorang. Jika mendapat awalan 'su' atau 'du' maka artinya menjadi perilaku yang baik (sucarita) dan perilaku tidak baik (ducarita) yang timbul melalui pikiran, ucapan, dan perbuatan (Davids \& William Stede, The Pali Text Society's Pali-English Dictionary". www.dharma.org.ru). Temperamen (carita) diartikan sebagai perbuatan baik atau perbuatan jahat. Dalam pengertian lain, dapat dinyatakan bahwa carita adalah kecenderungan yang termanifestasi dalam sebuah kebiasaan yang sering muncul (perbuatan baik/jahat)(Mingun, 2008: 2299).

Sedangkan Bodhi menyatakan bahwa "Temperament (carita) means personal nature, the character of a person as revealed by his or her natural attitudes and conduct (temperamen (Bodhi, 2012: 330-331). Temperamen setiap orang berbeda-beda dikarenakan keragaman kamma masa lampau mereka. 
Dalam Vimuttimagga disebutkan bahwa ada dua penyebab temperamen (carita) yaitu kebiasaan sebelumnya (puddācinna) dan elemen (dhātudosa). Bagaimana kebiasaan sebelumnya (puddācinna) menjadi penyebab carita? Dikatakan bahwa seseorang yang telah mengumpulkan perbuatan baik dengan cara yang benar terlahir di alam surga setelah meninggal jika terlahir kembali di alam manusia menjadi temperamen serakah (ragacarita). Jika pada kehidupan lampau banyak melakukan perbuatan pembunuhan, perbuatan kejam akan menjadi temperamen kebencian (dosacarita). Dalam kehidupan masa lampau senang dengan minuman yang memabukan akan terlahir di alam binatang setelah meninggal jika terlahir di alam manusia maka akan menjadi temperamen kebodohan (mohacarita) (Upatissa, 1961: 57).

Berkaitan dengan pertanyaan bagaimanakah elemen (dhātudosa) menjadi penyebab carita?. Jika elemen ekstensi dan kohesi ditingkatkan maka cenderung menjadi mohacarita, jika unsur mobilitas dan panas ditingkatkan maka akan menjadi dosacarita, jika menyeimbangkan semua elemen maka cenderung menjadi ragacarita. Dengan demikian unsur-unsur yang berbeda dapat menjadi penyebab perilaku/temperamen (Upatissa, 1961: 58).

Buddhaghosa dalam Visuddhimagga menyatakan bahwa berdasar beberapa pernyataan (mengacu pada Upatissa Thera) penyebab temperamen (carita) ada empat yakni: kebiasaan sebelumnya, elemen (unsur), keberadaan masa lalu, kamma dan akar terkait (hetu). Diantara keempat penyebab tersebut YM. Buddhaghosa hanya setuju kamma dan hetu sebagai penyebab temperamen (carita), penyebab lainnya beliau menyatakan tidak ada referensi pasti dalam teks Pali (Buddhaghosa, 1996: 45).

Temperamen (Carita) dapat diketahui memalui berbagai cara, dalam Visuddhimagga disebutkan bahwa: "bagaimana dapat diketahui bahwa 'orang ini memiliki temperamen serakah (lobha)' dan sebagainya”. Hal tersebut dapat dijelaskan sebagai berikut: 'Melalui sikap badan (iriyāpatha), melalui tindakan (kicca),
'Melalui cara makan (bhojana), cara melihat, dan sebagainya (dassanadito),

'Melalui jenis-jenis keadaan (mental) yang muncul (dhammappavatti),

'Maka temperamen dapat dikenali'. (Nanamoli, 2011: 96).

Visuddhimagga mengklasifikasikan temperamen menjadi enam jenis, yakni: ragacarita (serakah), dosacarita (benci), mohacarita (bodoh), saddhācarita (yakin), buddhicarita (pandai), dan vitakkacarita (spekulatif) (Nanamoli, 2011: 96). Namun demikian teks menunjukan bahwa enam jenis temperamen ini dapat dikelompokkan menjadi tiga pasang sifat bertentangan untuk tiga kategori yakni mendekati/menyenangi, menghindari/membenci, atau netral/acuh, yakni: (1) ragacarita (tamak)/saddhācarita (yakin); (2) dosacarita (benci)/buddhicarita (pandai); (3) mohacarita (bodoh)/vitakkacarita (spekulatif). Dua kutub masing-masing umumnya mewakili aspek terampil dan tidak terampil dari setiap jenis karakter tersebut.

Istilah ragacarita dapat didefinisikan sebagai orang yang memiliki keserakahan, orang yang memiliki sifat pribadi serakah. Dalam diri seorang lobhacarita sering terjadi keadaan-keadaan seperti: munafik/inkonsistensi (māyā), sombong (māna), banyak keinginan (atricchatā), ketidakpuasaan (asantuțțhì), penipu (sātheyya), pesolek (singa), pikiran berubah-ubah (cāpalya).

Dosacarita adalah karakteristik seseorang yang dominan sifat kebenciannya atau orang yang mengambil obyek dengan kemarahan. Dalam diri seorang dosacarita sering terjadi keadaan-keadaan seperti: pemarah (kodha), pendendam (upanāha), meremehkan (makkha), dengki (paḷāsa), iri hati (issā), dan kikir (macchariya).

Mohacarita adalah seseorang yang memiliki sifat pribadi khayalan serta orang yang mengambil obyek dengan delusi, dalam dirinya sering terjadi keadaan-keadaan seperti: malas (thina), lamban (midha), penuh kegelisahan (uddhacca), kekhawatiran (kukkucca), penuh keraguan (vicikicchā), melekat (duppatinissaggita), tidak penuh kesadaran (asampajañña). 
Saddhācarita adalah karakteristik seseorang yang memiliki sifat penuh keyakinan, dalam dirinya sering terjadi keadaankeadaan seperti: murah hati (muttacāgatā), mudah percaya terhadap hal-hal yang patut dipercaya (pasādaniyesu thā̄nesu pāsado), keinginan mengunjungi orang suci (ariyānam dassanakāmatā), keinginan mendengarkan dhamma (saddhammamsotukāmatā), kejujuran (amāyāvitā), sederhana (asațhāta), dan periang (pāmojjabahulata).

Buddhicarita mengacu pada seseorang yang memiliki sifat pribadi cerdas, dalam dirinya sering terjadi keadaankeadaan seperti: Suka memiliki teman baik (kalyānamittatā), penuh perhatian dan kesadaran (satisampajaňnatā), mudah menyapa (savacassatā), terlatih dalam kewaspadaan (jāgariyānuyogo), batin mudah tergugah dalam hal kebenaran (samivega), memiliki kesederhanaan dalam hal makanan (bhojane mattaññutatā).

Vitakkacarita adalah karakteristik seseorang yang memiliki sifat spekulatif, dalam dirinya sering terjadi keadaan-keadaan seperti: banyak bicara (bhassabahulatā), perencana (rattim dhūmayānā), gagal menyelesaikan tugas (anavatthitakiccatā), gelisah (hurahuram dhāvanā), suka berkumpul (ganārāmatā), aktif (divāpajjalanā), dan bosan melakukan hal yang bermanfaat (kusalānuyoge).

Dalam praktik meditasi buddhis jenis Samatha Bhavana yang memiliki 40 jenis objek, seorang meditator harus memahami satu objek yang sesuai dengan temperamennya (carita) sendiri sehingga ia dapat meraih hasil yang optimal. Proses penentuan objek meditasi yang sesuai dengan temperamen meditator akan lebih praktis dan efektif jika ada instrumen yang valid dan reliabel. Namun demikain, bukanlah perkara mudah untuk menyusun sebuah instrumen pengklasifikasian temperamen. Temperamen merupakan sebuah psychological concept yang dirumuskan secara hipotetik untuk menjelaskan fenomena psikologis yang nampak pada perilaku manusia. Atribut psikologis lebih abstrak dan batasannya tidak selalu dapat diterima dan diberlakukan secara umum. Pengukuran terhadap atribut psikologis dapat dilakukan mel- alui tanda-tanda keprilakuan yang mencerminkan adanya atribut yang akan diukur, biasanya disebut behavioral indicator (Azwar, 2012: 22).

Pengukuran ciri terpendam seperti temperamen pada responden menggunakan stimulus yang akan ditanggapi dengan harapan respon mencerminkan atribut yang diukur, hasil pengukuran tersebut akan diskor dan ditafsirkan. Hanya saja sering muncul keraguan apakah instrument yang dipakai sebagai stimulus itu mampu mengungkapkan dengan benar ciri yang terpendam. Seyogyanya sebelum instrumen sebelum digunakan harus divalidasi sehingga hasil pengukuran melalui instrumen tersebut dipercaya, instrumen terlebih dahulu dikembangkan melalui berbagai pengujian, baik teoritis maupun empiris. Untuk menghasilkan instrumen yang valid dan reliabel diperlukan langkah-langkah yang sistematis dan prosedural sehingga hasilnya dapat dipertanggung jawabkan secara ilmiah. Azwar (2012) menyatakan bahwa alur kerja dalam penyusunan skala psikologis yang merupakan langkah dasar proses pengembangan instrumen terdiri dari beberapa langkah, yakni:

(1) melakukan identifikasi tujuan ukur; (2) membatasi kawasan domain ukur berdasarkan konstruk yang didefinisikan oleh teori yang dipilih; (3) mengoperasionalkan aspek ke dalam bentuk indikator keperilakuan; (4) menuangkan indikator-indikator keperilakuan beserta dimensi ke dalam kisi-kisi atau blue print, sebelum menentukan metode penskalaan; (5) tahap penulisan item, dalam tahap ini harus memperhatikan kaidah-kaidah penulisan yang telah ditentukan; (6) review pertama dilakukan oleh peneliti, review kedua dilakukan oleh para ahli (expert judgement) untuk meloloskan item dalam tahap evaluasi kualitatif. Hanya item yang dinyatakan valid yang boleh diujicobakan secara empirik di lapangan; (7) mengestimasi reliabilitas; (8) melakukan validasi konstruk; (9) kompilasi final yaitu merakit instrumen dengan tampilan menarik.

Instrument yang dikembangkan harus memenuhi unsur validitas dan reliabilitas. Validitas mengacu pada sejauh mana hasil pengukuran suatu instrumen dapat ditafsirkan terhadap atribut yang diukur. Salah satu validitas yang harus terpenuhi dalam sebuah instrumen adalah validitas konstruk. Allen \& 
Yen, dalam Azwar (2013: 45) menyatakan bahwa validitas konstruk adalah validitas yang menunjukan sejauh mana hasil tes mampu mengungkap suatu trait atau suatu konstrak teoretik yang hendak diukurnya. Naga (2013: 321) menyatakan bahwa validitas konstruk mirip dengan validitas isi dan wajah, jika validitas isi memperhatikan materi di dalam alat ukur, maka validitas konstruk memperhatikan atribut konstruk di dalam alat ukur. Untuk pemeriksaan validitas konstruk dapat digunakan beberapa metode yakni, metode konvergensi, metode diskriminan, dan dapat menggunakan analisis faktor.

Istilah reliabilitas mempunyai berbagai nama, namun gagasan pokok yang terkandung dalam konsep reliabilitas adalah sejauh mana hasil suatu proses pengukuran dapat dipercaya (Abdullah), 2007: 7). Tinggi rendahnya reliabilitas sesungguhnya tidak dapat diketahui secara pasti, namun dapat diestimasi. Berbagai teknik estimasi telah dikembangkan oleh para ahli dengan tujuan memberikan indikasi akurasi dan kecermatan hasil ukur, salah satu indikator adanya akurasi dan kecermatan adalah koefisien reliabilitas (Uno, Hamzah. B, Herminanto Sofyan, dan I Made Candiasa, 2001: 141).

Wahyu Widhiarso menyatakan bahwa untuk mengestimasi reliabilitas data hasil pengukuran yang bersifat multidimensi dapat menggunakan koefisien reliabilitas komposit McDonald (Widhiarso, 2015). Dalam penelitian ini untuk mengestimasi reliabilitas data hasil pengukuran menggunakan koefisien reliabilitas komposit McDonald yang diberi nama Construct Reliability $(\mathrm{CR})$ yang juga disebut koefisien Omega $(\omega)$. Koefisien reliabilitas ini berbasis pada analisis faktor konfirmatori yang merupakan bagian dari Structur Equation Modeling (SEM). Abdullah menyatakan, untuk mendapatkan reliabilitas instrumen pada menu pemodelan SEM dapat dihitung berdasarkan factor loading dan measurement error yang didapat dari second order CFA. Rumus yang digunakan uji reliabilitas adalah rumus Construct Reliability (CR) dan Variance Extracted (VE) (Abdullah, 2007: 35). Untuk pemeriksaan validitas dan reliabilitas instrumen dapat menggunakan analisis faktor.

Secara umum analisis faktor dibagi menjadi dua bagian yakni analisis faktor ekploratori (Exploratory Factor Analysis) dan analisis faktor konfimatori (Confirmatory Factor Analysis). Heck dalam Supranto menguraikan analisis konfirmatori sebagai pendekatan validasi konstruk/konsep (approach to construct validation) artinya, kesimpulan mengenai konsep yang tidak terlihat dapat dibuat berdasar pada analisis faktor konfirmatori (Supranto, 2010: 255-256). Salah satu program yang dapat digunakan dalam pendekatan dengan Confirmatory Faktor Analysis (CFA) adalah Struktural Equation Modeling (SEM), softwarenya LISREL (Latan, 2013: 1). Dalam penelitian ini tipe SEM yang digunakan adalah tipe CB-SEM. Menurut Bollen dan Long, ada lima proses yang harus dianalisis dalam CB-SEM, yaitu: spesifikasi model, identifikasi model, estimasi model, evaluasi model, dan respesifikasi model (Latan, 2013: 42-54).

Penelitian berkaitan dengan tema temperamen (carita) pernah dilakukan oleh Nicholas T. Van Dam, Anna Brown, Tom B. Mole, Jake H. Davis, Willoughby B. Britton, dan Judson A. Brewer dengan judul "Development and Validation of the Behavioral Tendencies Questionnaire". Dalam penelitian tersebut dikembangkan instrumen berupa kuesioner berdasarkan kategori temperamen menurut persepktif buddhis dan mengaitkannya dengan taksonomi dan kecenderungan perilaku. Instrumen yang dikembangkan berupa kuesioner tertutup, preferensi untuk item dimodelkan menggunakan Latent Class Analysis dengan melakukan dua kali uji coba. Sampel pada uji coba pertama berjumlah 394 dan uji coba kedua 504 responden. Kuesioner berisi sejumlah pernyataan tentang kecenderungan yang dimiliki orang. Responden diharuskan memilih opsi jawaban paling benar dan tidak benar untuk tiga pilihan atas sebuah pernyataan. Hasil akhir diperoleh instrumen 13 blok yang merupakan kuesioner psikologis yang valid dan reliabel secara historis berdasarkan kecenderungan perilaku yang diberi nama Behavioral Tendencies Questionnaire. 


\section{Metode}

Prosedur

Penelitian ini termasuk penelitian Research and Development yang berusaha menghasilkan produk berupa instrument pengukur kategorisasi temperamen (carita) dalam perspektif buddhis berdasar Kitab Visuddhimagga yang valid dan reliable. Prosedur pengembangan instrument dalam penelitian ini adalah sebagai berikut:

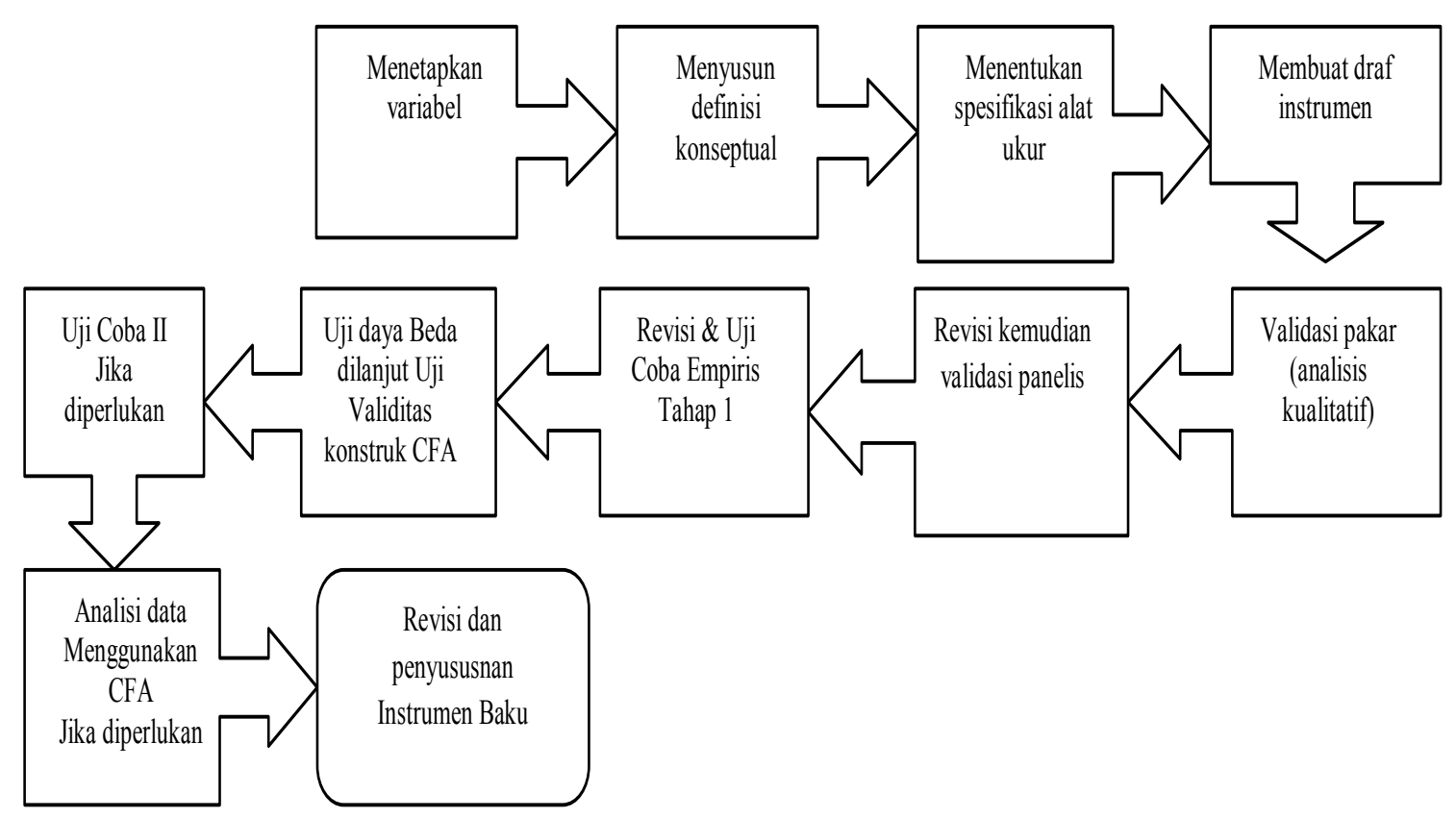

Gambar 1. Prosedur Pengembangan Instrumen

Proses pengujian dalam penelitian ini melalui dua tahap, yakni pengujian secara teoritis dan empiris. Pengujian teoritis dilakukan oleh pakar (expert judgement) dan panelis. Validasi pakar dianalisis secara kualitatif sedangkan validasi panelis diuji secara kuantitatif menggunakan koefisien validitas isi Aiken's $\mathrm{V}$ untuk validasi butir dan reliabilitas antarrater diuji menggunakan rumus Hoyt. Pengujian empiris melalui analisis statistik menggunakan Structural Equation Modeling (SEM).

\section{Subjek Penelitian}

Jumlah sampel yang dijadikan responden untuk pengujian empiris dalam penelitian mengikuti apa yang disarankan oleh Loehlin dalam Latan yang menyatakan bahwa untuk SEM sampel yang dibutuhkan adalah sebanyak 100-200. Tahap pengujian empiris melibatkan 103 mahasiswa Perguruan Tinggi Keagamaan Buddha (PTKB) baik negeri maupun swasta di Indonesia terutama di Pulau Jawa, yaitu: (1) STAB Syailendra Semarang, (2) STAB Negeri Raden Wijaya, Wonogiri, (3) STAB Maha Prajna Jakarta, (4) STAB Nalanda, Jakarta, (5) STAB Dutavira, Jakarta, dan (6) STAB Negeri Sriwijaya Tangerang Banten.

\section{Pengukuran}

Untuk mengkategorisasikan temperamen (carita) digunakan instrumen berupa kuesioner, yang terdiri dari enam dimensi dan 34 indikator. Berikut adalah blue print alat ukur kategorisasi temperamen (carita) 
Tabel 1 Blue Print Alat Ukur Kategorisasi Temperament (Carita)

\begin{tabular}{|c|c|c|c|}
\hline DIMENSI & INDIKATOR & $\begin{array}{c}\text { NOMOR BUTIR } \\
(+)\end{array}$ & $\begin{array}{c}\text { PERNYATAAN } \\
(-)\end{array}$ \\
\hline \multirow{6}{*}{ A. Ragacarita } & 1. Munafik/inkonsistensi(Sātheya) & 1 & 2,3 \\
\hline & 2. Sombong (Māna) & 4 & 5,6 \\
\hline & 3. Banyak Keinginan (Atricchatā) & 7,8 & \\
\hline & 4. Ketidakpuasaan (Asantutthī) & 10 & 9 \\
\hline & 5. Penipu (Sātheya) & & 11,12 \\
\hline & 6. Pesolek (Siňga) & 13,14 & \\
\hline \multirow[t]{6}{*}{ B. Dosacarita } & 7. Pemarah (Kodha) & 15,17 & 16 \\
\hline & 8. Pendendam (Upanāha) & 19 & 18 \\
\hline & 9. Bersyukur (Makkha) & 20,21 & \\
\hline & 10. Meremehkan (Palasa) & 23 & 22 \\
\hline & 11. Iri Hati(Issā) & 24 & 25 \\
\hline & 12. Kikir (Macchariya) & 27 & $26,28,29$ \\
\hline \multirow[t]{6}{*}{ C. Mohacarita } & 13. Malas (Thina) & 31,32 & 30 \\
\hline & 14. Lamban (Middha) & 33,35 & 34 \\
\hline & 15. Penuh Kegelisahan (Uddhacca) & $36,37,38$ & \\
\hline & 16. Penuh Keraguan (vicikicca) & $39,40,41$ & \\
\hline & 17. Melekat (Duppatinissaggita) & $43,44,45$ & 42 \\
\hline & $\begin{array}{l}\text { 18. Tidak Penuh Kesadaran } \\
\text { (Asampajanna) }\end{array}$ & 48,49 & 46,47 \\
\hline \multicolumn{2}{|c|}{ D. Saddhacarita19. Murah Hati (Muttacāgatā) } & $50,51,52,53$ & \\
\hline & $\begin{array}{l}\text { 20. Mudah Percaya } \\
\text { (Pasādaniyesuthānesu pasādo) }\end{array}$ & $54,55,56$ & \\
\hline & $\begin{array}{l}\text { 21. Keinginan mengunjungi orang suci } \\
\text { (Ariyānandassana Kāmatā) }\end{array}$ & $57,58,59$ & \\
\hline & $\begin{array}{l}\text { 22. Keinginan Mendengarkan dhamma } \\
\text { (Saddhammamsotukāmatā) }\end{array}$ & 62 & 60,61 \\
\hline & 23. Kejujuran (Amāyāvitā) & 63,66 & 64,65 \\
\hline & 24. Sederhana (Assatthata) & 68,69 & 67 \\
\hline & 25. Periang (Pāmojjabahulatā) & $70,71,72$ & \\
\hline \multirow{5}{*}{ E. Buddhicarita } & 26. Mudah Bergaul (Kalyānamittatā) & $73,74,75,76$ & \\
\hline & $\begin{array}{l}\text { 27. Penuh perhatian dan kesadaran } \\
\text { (Satisampajaňnatā) }\end{array}$ & $77,78,79$ & 80 \\
\hline & 28. Mudah menyapa (Savacassatā) & 84,85 & $81,82,83$ \\
\hline & $\begin{array}{l}\text { 29. Memiliki usaha benar } \\
\text { (Jāgariyānuyogo) }\end{array}$ & & 86,87 \\
\hline & 30. Memiliki kemendesakan (Saṁvega) & $88,89,90,91$ & \\
\hline \multirow[t]{4}{*}{ F. Vittakacarita } & 31. Banyak bicara (Bhassabahulata) & $93,94,95$ & 92 \\
\hline & 32. Perencana & $96,97,98$ & \\
\hline & $\begin{array}{l}\text { 33. Gagal menyelesaikan tugas } \\
\text { (Anavathitakiccata) }\end{array}$ & 101 & $99,100,102$ \\
\hline & 34. Pikiran Gelisah (Hurahuramdhavana) & 103,104 & \\
\hline
\end{tabular}

Validitas

Analisis statsistik digunakan pada tahap validasi empiris dan pengukuran model dikonfirmasi menggunakan Confirmatory Factor Analysis (CFA) dengan bantuan software Lisrel 8.80. Validitas butir diukur dengan melihat nilai factor loading. Sebelum analisis dengan CFA, dilakukan seleksi butir dengan uji daya beda (daya diskriminasi) menggunakan formula koefisien korelasi product momen Pearson yang kemudian dikoreksi dengan Item Correlated Total Correlation. Item yang 
memiliki daya beda memuaskan diseleksi lanjut untuk tabulasi menggunakan second order CFA untuk mengkonfirmasi kesesuaian konstruk teori yang dijadikan acuan dalam pengembangan instrumen dengan data empiris (kelayakan model/Goodness of Fit).

\section{Reliabilitas}

Rumus yang digunakan uji reliabilitas adalah rumus Construct Reliability (CR) dan Variance Extracted (VE). Nilai reliabilitas konstruk (CR) yang disarankan adalah $\geq 0,7$, sedangkan ukuran kelayakan variance extracted (VE) disarankan $\geq 0,5$ (Hendryadi \& Suryani, 2014: 18). Untuk mengetahui hubungan antar variabel digunakan structural model fit, yaitu untuk menguji signifikansi dari koefisien estimasi. Nilai $t$ value $>1,96$ (alpha 0,05 ) dapat dinyatakan bahwa hubungan antar variabel signifikan. Uji coba akan direncanakan dua kali namun jika dalam uji coba pertama sudah mendapatkan instrumen valid dan reliabel maka uji coba kedua tidak dilakukan.

\section{Hasil}

\section{Pengujian Teoritis}

1. Validasi Melalui Expert Judgement

Validasi teoritis melibatkan dua orang expert, yakni Bhikkhu Santacitto, P.hD pakar dalam bidang buddhis studies dan Waluyo, M.Pd ahli dalam bidang pengembangan isntrumen. Pakar memberikan penilaian terhadap kesesuaian butir mengukur indikator dengan lima alternatif pilihan, dari sangat tepat sampai sangat tidak tepat. Jumlah butir pernyataan dalam draft instrumen yang divalidasi sebanyak 109 butir hasil pengembangan dari 34 indikator. Selain itu, ahli juga diminta agar memberikan masukan terkait draft instrumen awal yang kemudian dianalisis secara kualitatif.

Hasil telaah pakar pertama memberikan beberapa masukan antara lain: 1) penulisan bahasa Pali harus sesuai dengan tanda baca; 2) penambahan beberapa indikator (dari 34 indikator menjadi 40 indikator). Indikator yang ditambahkan yaitu:

Tabel 2. Penambahan Indikator Hasil Expert Judgement

\begin{tabular}{ll}
\hline \multicolumn{1}{c}{ Dimensi } & \multicolumn{1}{c}{ Indikator } \\
\hline Ragacarita & Pikiran Berubah-ubah (Cāpalya) \\
Mohacarita & Kekhawatiran (Kukkucca) \\
Saddhacarita & Sederhana (Asațhāta) \\
Buddhicarita & Sederhana dalam hal makan \\
& (Bhojane Mattaññutatā) \\
Vitakkacarita & Suka berkumpul (Gan̄ārāmatā) \\
& Aktif (Divāpajjalanā \\
\hline
\end{tabular}

Hasil telaah pakar kedua (Bapak Waluyo, M.Pd) memberikan beberapa masukan antara lain: 1) perbaikan kalimat dalam definisi operasional; 2) perbaikan kalimat dalam butir penyataan yang efektif; 3) penambahan kolom untuk pernyatan yang favorable dan unfavorable; 4) kesalahan dalam pengetikan. Setelah mendapat masukan dari kedua pakar, draft instrumen direvisi yang selanjutnya dimintakan validasi kepada panelis. Jumlah butir pernyataan untuk divalidasi oleh panelis berjumlah 112 butir hasil dari pengembangan 40 indikator.

\section{Validasi oleh Panelis}

Validasi teoritis dilanjutkan melalui penilaian kepada 15 orang panelis yang ber kenan memvalidasi, terdiri dari dosen pendidikan agama Buddha, romo pandita, dan guru pendidikan agama Buddha (SD, SMP, SMA/ SMK). Panelis dimintakan menilai kesesuaian antara butir dengan indikator dengan alternatif pilihan dari sangat tepat sampai sangat tidak tepat.

Pemeriksaan validitas butir yang dilakukan oleh panelis menggunakan indeks validitas Aiken. Butir dipertahankan (butir valid) jika nilai $V \geq 0.2$. Hasil analisis Indeks Kecocokan Aiken ada 19 indikator yang me- 
miliki nilai $V<0,2$ yaitu antara 0,17 sampai 0,18 . Nomor butir yang memiliki nilai Indeks Kecocokan Aiken $<0,2$ secara bertutut-turut yaitu nomor butir: 12,17,28,30,34,39,45,46,4 8,53,65,69,71,73,80,82,95,102, dan 111.

Pengujian reliabilitas antarrater $\left(r^{\wedge} 11\right)$ menggunakan rumus Hoyt, berikut adalah hasil penghitungan reliabilitas antarrater berdasarkan Rumus Hoyt:

$r_{11}=\frac{R J K_{b}-R J K_{e}}{R J K_{b}}=\frac{0.973044-0.214598}{0.973044}=0,779457$

Total ada 93 butir yang dinyatakan valid dari 112 butir yang divalidasi secara teoritik oleh panelis. Namun demikian, karena indikator dari instrumen yang dikembangkan berjumlah 40 indikator, maka hanya dipilih 80 butir instrumen yang valid. Setiap indikator dipilih 2 butir valid sebagai instrumen yang akan diuji coba untuk pengujian empiris kepada responden.

\section{Pengujian Empiris}

Pengujian empiris dilakukan dengan tujuan untuk mengetahui validitas instrumen apakah benar-benar mengukur apa yang seharusnya diukur sesuai dengan tujuan pengukuran yang dalam hal ini adalah mengukur gukuran yang dalam hal ini adalah mengukur temperamen (carita). Data hasil uji empiris yang diambil dari 103 mahasiswa PTKB akan dianalisis menggunakan Confirmatory Factor Analysis (CFA) dengan bantuan software Lisrel 8.80, namun sebelum dianalisis dengan CFA terlebih dahulu dilakukan seleksi butir menggunakan uji daya beda.

\section{Uji Daya Beda}

Pengujian daya diskriminasi item dilakukan dengan cara menghitung koefisien korelasi antara distribusi skor butir dengan distribusi skor skala itu sendiri, penghitungan tersebut akan menghasilkan koefisien korelasi item total (r_ix). Formulasi korelasi yang digunakan untuk penghitungan daya beda sebagai bentuk validitas item dalam penelitian ini menggunakan formula koefisien korelasi product moment Pearson dan Corrected Item Total Correlation. Item dikatakan valid jika terjadi korelasi yang kuat dengan skor totalnya (Priyanto, 2009: 119). Berdasarkan hasil analisis ada 32 butir yang memiliki daya beda tidak memuaskan. Di bawah ini adalah tabel rekapitulasi hasil uji daya beda butir instrumen temperamen (carita) yang tidak memuaskan sebelum dan sesudah dikoreksi: 
Tabel 3. Rekapitulasi Hasil Uji daya Beda yang Tidak Memuaskan

\begin{tabular}{|c|c|c|c|c|}
\hline \multirow[t]{2}{*}{$\begin{array}{l}\text { NO. } \\
\text { BUTIR }\end{array}$} & \multicolumn{2}{|c|}{$\begin{array}{l}\text { KRITERIA } \\
\text { PENILAIAN }\end{array}$} & \multirow[t]{2}{*}{$\begin{array}{l}\text { KRITERIA } \\
\text { BATASAN }\end{array}$} & \multirow[t]{2}{*}{ STATUS } \\
\hline & r_ix Sebelum dikoreksi & r_ix Setelah dikoreksi & & \\
\hline 3 & 0.12 & 0.097 & 0.2 & Tidak Memuaskan \\
\hline 6 & 0.158 & 0.132 & 0.2 & Tidak Memuaskan \\
\hline 7 & 0.192 & 0.167 & 0.2 & Tidak Memuaskan \\
\hline 10 & 0.078 & 0.053 & 0.2 & Tidak Memuaskan \\
\hline 13 & 0.1 & -0.017 & 0.2 & Tidak Memuaskan \\
\hline 15 & -0.111 & -0.133 & 0.2 & Tidak Memuaskan \\
\hline 17 & 0.065 & 0.041 & 0.2 & Tidak Memuaskan \\
\hline 19 & 0.164 & 0.143 & 0.2 & Tidak Memuaskan \\
\hline 22 & 0.181 & 0.155 & 0.2 & Tidak Memuaskan \\
\hline 26 & 0.086 & 0.061 & 0.2 & Tidak Memuaskan \\
\hline 28 & 0.106 & 0.085 & 0.2 & Tidak Memuaskan \\
\hline 29 & 0.198 & 0.17 & 0.2 & Tidak Memuaskan \\
\hline 34 & 0.106 & 0.081 & 0.2 & Tidak Memuaskan \\
\hline 40 & -0.01 & -0.021 & 0.2 & Tidak Memuaskan \\
\hline 41 & -0.041 & -0.067 & 0.2 & Tidak Memuaskan \\
\hline 43 & 0.066 & 0.041 & 0.2 & Tidak Memuaskan \\
\hline 46 & 0.036 & 0.011 & 0.2 & Tidak Memuaskan \\
\hline 48 & 0.017 & -0.006 & 0.2 & Tidak Memuaskan \\
\hline 50 & -0.024 & -0.05 & 0.2 & Tidak Memuaskan \\
\hline 51 & 0.034 & 0.007 & 0.2 & Tidak Memuaskan \\
\hline 54 & 0.052 & 0.031 & 0.2 & Tidak Memuaskan \\
\hline 55 & -0.047 & -0.072 & 0.2 & Tidak Memuaskan \\
\hline 57 & -0.27 & -0.293 & 0.2 & Tidak Memuaskan \\
\hline 60 & -0.064 & -0.087 & 0.2 & Tidak Memuaskan \\
\hline 61 & 0.022 & -0.001 & 0.2 & Tidak Memuaskan \\
\hline 63 & 0.047 & 0.021 & 0.2 & Tidak Memuaskan \\
\hline 66 & 0.061 & 0.034 & 0.2 & Tidak Memuaskan \\
\hline 67 & -0.114 & -0.137 & 0.2 & Tidak Memuaskan \\
\hline 69 & 0.026 & 0.001 & 0.2 & Tidak Memuaskan \\
\hline 72 & 0.108 & 0.084 & 0.2 & Tidak Memuaskan \\
\hline 76 & 0.089 & 0.064 & 0.2 & Tidak Memuaskan \\
\hline 77 & 0.08 & 0.057 & 0.2 & Tidak Memuaskan \\
\hline
\end{tabular}

32 butir yang memiliki daya beda rendah didroop karena butir tersebut tidak mampu membedakan individu yang memiliki dan tidak memiliki atribut yang diukur. Meskipun demikian, semua indikator memiliki wakil butir yang valid. Dimensi Ragacarita yang terdiri dari 14 butir hasil pengembangan dari 7 indikator, ada 5 butir yang tidak valid yaitu butir no $3,6,7,10,13$. Contoh butir yang tidak valid dari dimensi Ragacarita yaitu butir no 3 hasil pengembangan indikator sombong (māna), dengan pernyataan "Saya merasa lebih superior dibanding orang lain dalam banyak hal". Analisis mengapa butir ini tidak valid ditengarai karena responden cenderung tidak mengakui jika ditanya dengan pernyat- aan yang terlalu 'vulgar' seperti itu. Karena responden tidak mengungkapkan kondisi sesungguhnya yang ada pada dirinya berakibat saat data dianalisis secara empiris menggunakan ujibeda, butir tersebut menjadi tidak mampu membedakan antara responden yang memiliki karakter sombong atau tidak. Dimensi Dosacarita yang terdiri dari 12 butir hasil pengembangan dari 6 indikator, ada 5 butir yang tidak valid. Contoh butir valid dari dimensi Dosacarita adalah butir no 16 yang merupakan pengembangan indikator pemarah (Kodha) dengan pernyataan "Saya mudah tersinggung untuk hal sepele sekalipun". Butir tersebut jelas mencerminkan dari sikap pemarah (kodha) karena bentuk asli dari 
pemarah adalah keadaan seseorang yang tidak mampu menanggung objek atau keinginan meninggalkan objek (keengganan yang berlebihan).

Hasil uji beda dimensi Mohacarita ada 4 butir yang tidak valid total 14 butir hasil pengembangan 7 indikator. Contoh butir tidak valid dimensi Mohacarita adalah no 34 dari indikator kekhawatiran (kukkucca) dengan pernyataan "aya sulit fokus ketika mengerjakan sesuatu karena perasaan khawatir". Butir ini tidak valid lebih karena konstruksi butir yang bermakna ganda sehingga tidak valid, bisa saja responden tidak fokus tapi bukan karena khawatir tapi karena sebab lain. Dimensi Sadhacarita ada 5 butir yang tidak valid. Contoh butir yang tidak valid adalah nomor 48 dari indikator senang mendengarkan Dhamma (Saddhammamsotukāmatā) dengan pernyataan 'Saya senang melakukan sharing Dhamma (Dhammasakacca), butir ini tidak valid karena memang kurang mewakili indikator. Dalam dhammasakacca meskipun ada mendengarkan Dhamma namun dalam kegiatan tersebut lebih mengarah kepada diskusi Dhamma secara aktif yang tidak hanya mendengarkan. Dimensi Buddhicarita ada 5 butir yang tidak valid dari total 12 butir hasil pengembangan 6 indikator. Contoh butir valid dari dimensi ini adalah butir no 59 dari indikator Mudah menyapa (Savacassatā) dengan pernyataan "Saya sering menyapa orang lain terlebih dahulu". Butir tersebut secara teoritis pun jelas mencerminkan dari sikap mudah menyapa yang merupakan perilaku nyata dari karakter seseorang yang menunjukan keramahan tanpa kesombongan. Dimensi Vitakkacarita ada 5 butir tidak valid dari total 14 butir hasil pengembangan dari 7 indikator. Contoh butir yang tidak valid adalah butir no 69 indikator Perencana (Rattim Dhūmayānā) dengan pernyataan "Setiap kegiatan yang saya lakukan selalu direncanakan dengan matang". Meskipun indikator Rattim Dhūmayānā diterjemahkan perencana namun secara harfiah frase tersebut berarti 'berasap di malam hari'. Ini sebenarnya mengacu kepada orang yang selalu berpikir untuk merencanakan sesuatu. Jadi pikirannya selalu berasap. Dalam konteks ini, meskipun berencana itu hal yang terkadang baik dilakukan, ini bukan kualitas positif.

2. Uji Validitas Konstruk Menggunakan Second Order Confirmatory Factor Analysis (CFA).

Setelah dilakukan uji daya beda, 48 butir yang memilik uji daya beda memuaskan digunakan untuk uji validitas konstruk. Uji validitas konstruk menggunakan second order confirmatory factor analysis. Hanya 40 butir yang dikutsertakan dalam uji validitas konstruk (setiap indikator diambil satu butir yang memiliki daya beda paling memuaskan). Implikasi dari hal tersebut adalah adanya perubahan pengkodean indikator.

Proses pengujian pada second order CFA dilakukan melalui dua jenjang yakni: (1) analisis dari dimensi ke indikator-indikatornya. Dalam penelitian ini menguji enam dimensi ke indikatornya yang berjumlah 40 indikator; (2) analisis dari konstruk laten ke dimensinya, dalam hal ini adalah analisis dari konstruk temperamen/carita (C) ke konstruk dimensinya.

Langkah pertama dalam pengujian melalui CFA adalah menguji kesesuaian (fit) model antara konsep teoritis dengan data empirik (data hasil uji coba). Model dikatakan sesuai antara teori dengan data empirik jika memenuhi apa yang dipersyaratkan dalam goodness of fit. Hasil output second order CFA pertama kali terdapat Heywood cases dan model belum fit dikarenakan persyaratan Goodnes of Fit tidak terpenuhi. Hal tersebut juga nampak dalam diagram second order CFA berdasarkan standard solution ada factor loading yang kurang dari 0,5 yaitu indikator $F 7$ dengan nilai factorloading 0,49 . Berikut adalah gambar diagram second order CFA berdasar standard solution: 


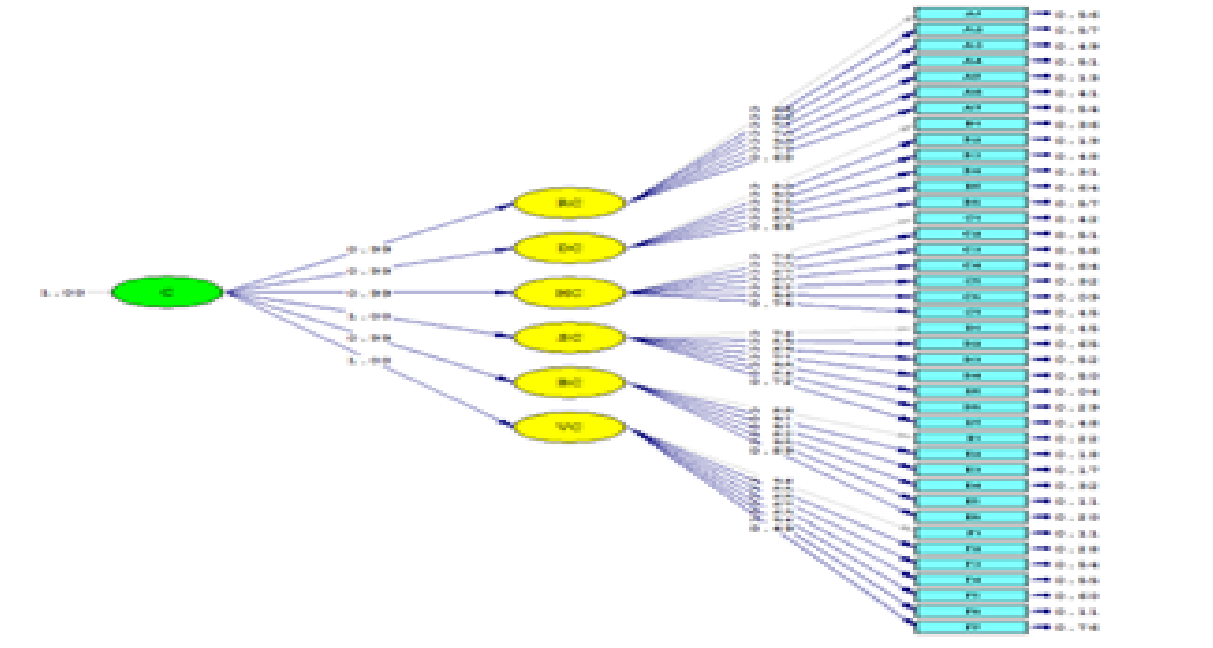

Gambar 2. Diagram Second Order CFA Instrumen

Temperamen (Carita) Berdasar Visudhi Magga Berdasarkan

Standardized Solution

Untuk mendapatkan model yang fit lum terpenuhi sehingga perlu memodifikasi maka perlu dilakukan modifikasi model yaitu dengan mengeluarkan indikator yang tidak valid (yang mempunyai nilai factorloading < $0,5)$. Setelah itu kemudian dianalisis kembali dengan menggunakan second order CFA. Setelah indikator F7 dikeluarkan ternyata model belum fitt, hal tersebut nampak pada kriteria persyaratan goodnes of fit model bemodel agar diperoleh model yang fit. Modifikasi dilakukan berdasarkan saran pada modification indicies yaitu dengan membiarkan kesalahan pengukuran saling berkorelasi. Berikut adalah rekapitulasi dari output Lisrel tentang goodnes of fit setelah modifikasi dibandingkan dengan sebelum modifikasi dengan indikator F7 didroop:

Tabel 4. Goodnes of Fit Model Sesudah Modifikasi Uji Empirik Instrumen Temperamen (Carita) Berdasarkan Visuddhimagga

\begin{tabular}{|c|c|c|c|c|}
\hline \multicolumn{2}{|l|}{ Goodnes of Fit } & \multirow{2}{*}{$\begin{array}{l}\text { Cut of Value } \\
(\leq 0 \\
\geq 0.05 \\
\geq 0.9 \mathrm{gf}, \leq 0.9 \mathrm{mf} \\
0.05-0.08 \mathrm{gf}, \geq 0.08 \mathrm{mf} . \\
\leq 0.05 \mathrm{gf}, \\
\text { Semakin kecil baik }\end{array}$} & \multicolumn{2}{|c|}{ Setelah Modifikasi } \\
\hline Absolute Fit Indices & $\begin{array}{l}\text { Chi Square }\left(x^{\wedge} 2\right) \\
\text { Probability } \\
\text { GFI } \\
\text { RMSEA } \\
\text { RMR } \\
\text { NCP }\end{array}$ & & $\begin{array}{l}1277,24 \\
0,00000 \\
0,61 \\
0,0093 \\
0,097 \\
601,24\end{array}$ & $\begin{array}{l}\text { Tidak fit } \\
\text { Marginal Fit } \\
\text { Acceptable fit } \\
\text { Marginal fit } \\
\text { Semakin kecil }\end{array}$ \\
\hline Incremental Fit Indices & $\begin{array}{l}\text { AGFI } \\
\mathrm{NFI} \\
\mathrm{CFI} \\
\mathrm{IFI} \\
\mathrm{RFI}\end{array}$ & $\begin{array}{l}\geq 0.9 \\
>0.90 ;>0.95 \\
\geq 0.9 \\
>0.90 ;>0.95 \\
>0.90 ;>0.95\end{array}$ & $\begin{array}{l}0,55 \\
0,96 \\
0,98 \\
0,98 \\
0,95\end{array}$ & $\begin{array}{l}\text { Fit } \\
\text { Fit } \\
\text { Fit } \\
\text { Fit }\end{array}$ \\
\hline Parsimony Fit indices & $\begin{array}{l}\text { PGFI } \\
\text { PNFI } \\
\text { AIC }\end{array}$ & $\begin{array}{l}\geq 0.60 \\
0.06-0.09 \\
\text { Semakin kecil baik }\end{array}$ & $\begin{array}{l}0,53 \\
0,87 \\
M^{*}=1485, \\
S^{*}=1560, \\
I^{*}=28497\end{array}$ & $\begin{array}{l}\text { Tidak fit } \\
\text { Tidak fit } \\
4 \text { Fit }\end{array}$ \\
\hline
\end{tabular}

\section{Structural Model Fit}

Structural model fit digunakan untuk menguji sifgnifikansi dari koefisien estimasi atau untuk melihat hubungan antar konstruk laten dengan indikatornya. Nilai $t$ value dari seluruh indikator laten ((t_hitung) dibandingkan dengan kriteria 1,96 sebagai (t_tabel) dengan taraf signifikansi 0,05 (5\%). Berikut adalah rekapitulasi dari nilai t-value, factorloading, std error dan lain-lain yang akan di- 
gunakan untuk analisis struktural model fit:

Tabel 5. Rekapitulasi Instrumen Temperamen (Carita) Berdasar Visuddhimagga Pengujian Empirik

\begin{tabular}{|c|c|c|c|c|c|c|c|c|}
\hline \multirow{2}{*}{$\begin{array}{l}\text { Nama } \\
\text { Konstruk }\end{array}$} & \multicolumn{3}{|c|}{ Goodnes of Fit } & \multirow{2}{*}{$\begin{array}{l}\text { Variabel } \\
\text { Endogen }\end{array}$} & \multirow{2}{*}{$\begin{array}{l}\text { Factor } \\
\text { Loading }\end{array}$} & \multirow[t]{2}{*}{ Std. Error } & \multirow[t]{2}{*}{ t value } & \multirow[t]{2}{*}{$R^{\wedge} 2$} \\
\hline & $x^{\wedge} 2$ & Df & $P$ value & & & & & \\
\hline \multirow[t]{7}{*}{$\mathrm{RC}$} & 1277,24 & 676 & 0,00000 & A1 & 0,66 & & & 0,44 \\
\hline & & & & A2 & 0,66 & 0,16 & 6,21 & 0,43 \\
\hline & & & & A3 & 0,71 & 0,17 & 6,67 & 0,51 \\
\hline & & & & A4 & 0,69 & 0,17 & 6,50 & 0,48 \\
\hline & & & & A5 & 0,93 & 0,19 & 8,35 & 0,86 \\
\hline & & & & A6 & 0,77 & 0,17 & 7,15 & 0,60 \\
\hline & & & & A7 & 0,68 & 0,17 & 6,42 & 0,47 \\
\hline \multirow[t]{6}{*}{ DC } & 1277,24 & 676 & 0,00000 & B1 & 0,80 & & & 0,63 \\
\hline & & & & B2 & 0,90 & 0,12 & 11,03 & 0,81 \\
\hline & & & & B3 & 0,73 & 0,11 & 8,26 & 0,53 \\
\hline & & & & B4 & 0,83 & 0,11 & 9,82 & 0,69 \\
\hline & & & & B5 & 0,59 & 0,091 & 7,70 & 0,35 \\
\hline & & & & B6 & 0,66 & 0,11 & 7,26 & 0,43 \\
\hline \multirow[t]{7}{*}{ MC } & 1277,24 & 676 & 0,00000 & $\mathrm{C} 1$ & 0,77 & & & 0,59 \\
\hline & & & & $\mathrm{C} 2$ & 0,70 & 0,10 & 7,62 & 0,49 \\
\hline & & & & C3 & 0,67 & 0,096 & 7,25 & 0,45 \\
\hline & & & & $\mathrm{C} 4$ & 0,60 & 0,096 & 6,34 & 0,36 \\
\hline & & & & C5 & 0,79 & 0,12 & 8,83 & 0,63 \\
\hline & & & & C6 & 0,95 & 0,12 & 11,17 & 0,90 \\
\hline & & & & $\mathrm{C} 7$ & 0,76 & 0,090 & 8,41 & 0,58 \\
\hline \multirow[t]{7}{*}{ SC } & 1277,24 & 676 & 0,00000 & D1 & 0,74 & & & 0,55 \\
\hline & & & & D2 & 0,59 & 0,11 & 6,19 & 0,35 \\
\hline & & & & D3 & 0,71 & 0,13 & 7,45 & 0,50 \\
\hline & & & & D4 & 0,70 & 0,13 & 7,44 & 0,50 \\
\hline & & & & D5 & 0,97 & 0,14 & 10,84 & 0,95 \\
\hline & & & & D6 & 0,85 & 0,10 & 10,67 & 0,73 \\
\hline & & & & D7 & 0,73 & 0,13 & 7,68 & 0,53 \\
\hline \multirow[t]{6}{*}{$B C$} & 1277,24 & 676 & 0,00000 & E1 & 0,87 & & & 0,76 \\
\hline & & & & E2 & 0,91 & 0,073 & 13,76 & 0,82 \\
\hline & & & & E3 & 0,91 & 0,050 & 19,84 & 0,82 \\
\hline & & & & E4 & 0,82 & 0,080 & 11,22 & 0,67 \\
\hline & & & & E5 & 0,94 & 0,074 & 15,16 & 0,89 \\
\hline & & & & E6 & 0,89 & 0,076 & 13,33 & 0,80 \\
\hline \multirow[t]{6}{*}{ VC } & 1277,24 & 676 & 0,00000 & F1 & 0,94 & & & 0,89 \\
\hline & & & & F2 & 0,85 & 0,050 & 14,00 & 0,72 \\
\hline & & & & F3 & 0,69 & 0,065 & 9,13 & 0,48 \\
\hline & & & & F4 & 0,67 & 0,069 & 8,72 & 0,46 \\
\hline & & & & F5 & 0,63 & 0,064 & 7,85 & 0,40 \\
\hline & & & & F6 & 0,94 & 0,053 & 19,24 & 0,88 \\
\hline \multirow[t]{6}{*}{ CARITA } & 1277,24 & 676 & 0,00000 & $\mathrm{RC}$ & 0,99 & 0,12 & 7,50 & 0,99 \\
\hline & & & & DC & 0,99 & 0,11 & 9,62 & 0,99 \\
\hline & & & & MC & 0,99 & 0,11 & 9,15 & 0,98 \\
\hline & & & & SC & 1,00 & 0,12 & 8,80 & 1,00 \\
\hline & & & & $B C$ & 0,99 & 0,12 & 11,08 & 0,99 \\
\hline & & & & VC & 1,00 & 0,12 & 12,71 & 1,00 \\
\hline
\end{tabular}

4. Pengujian Reabilitas Konsistensi Internal

Pengujian reabilitas konsistensi internal dilakukan berdasarkan penghitungan nilai Construct Reliability (CR) dan Variance
Extraced (VE) dengan menggunakan factor loading dan error. Berdasarkan hasil perhitungan, nilai Construct Reliability (CR) dan Variance Extraced (VE) melebihi nilai cut off 
$(C R \geq 0,7$ dan $V E \geq 0,5)$. Berikut adalah reak-

pitulasinya:

Tabel 6. Rekapitulasi Construct Reliability (CR) dan Variance Extraced (VE)

\begin{tabular}{llll}
\hline Variabel & CR $\geq 0,70$ & VE $\geq 0,50$ & Keterangan \\
\hline RC & 0,89 & 0,53 & Valid dan reliabel \\
DC & 0,88 & 0,54 & Valid dan reliabel \\
MC & 0,90 & 0,57 & Valid dan reliabel \\
SC & 0,91 & 0,59 & Valid dan reliabel \\
BC & 0,96 & 0,79 & Valid dan reliabel \\
VC & 0,91 & 0,64 & Valid dan reliabel \\
\hline
\end{tabular}

Berdasarkan pengujian secara teoritis dan empiris maka dapat disimpulkan bahwa instrumen temperamen (carita) berdasarkan Visuddhimagga yang memenuhi kriteria valid dan reliabel adalah berjumlah 39 indikator. Satu indikator yaitu F7 tidak valid karena memiliki nilai factorloading $<0,5$ sehingga indikator tersebut didroop. Rangkuman validitas dan reliabilitas instrumen temperamen (carita) beradasar Visuddhimagga yang dikembangkan berdasarkan pengujian teortis dan empiris adalah validitas (factor loading antara 0,99 - 1; nilai Construct Reliability: 0,99; dan nikai Varian Extraced: 0,99 yang dapat disimpulkan bahwa instrumen yang dikembangkan adalah valid dan reliabel.

\section{Pembahasan}

Validasi teoritis berdasarkan expert judgement, dapat dimpulkan bahwa kedua pakar banyak memberikan banyak sekali koreksi dan masukan terhadap draft instrumen. Namun demikian secara keseluruhan hasil uji dari pakar (expert judgement) menyatakan bahwa terdapat kesesuaian antara variabel dengan dimensi, dimensi dengan indikator, indikator dengan butir pernyataan. Penambahan enam indikator dari ahli seperti tertuang pada tabel 2 di atas setelah dilakukan croscheck terhadap Kitab Visuddhimagga dan Kitab Vimuttimagga memang benar. Berdasarkan analisis peneliti, ada beberapa indikator yang seharusnya dipisahkan menjadi dua, sedangkan oleh peneliti digabung, misalnya indikator penuh kegelisahan dan kekhawatiran (uddhaccakukkucca). Seharusnya indikator tersebut dipisahkan, karena antar uddhacca dengan kukkucca meskipun kondisi mental ini munculnya biasanya bersamaan namun itu adalah dua hal yang berbeda. Hal tersebut juga sesuai dengan pernyataan Piya Tan yang menyatakan bahwa uddhacca adalah sebuah keadaan agitasi mental yaitu kegelisahan jiwa (yang timbul, misalnya, dari berpikir tentang masa depan) kemudian merangsang kegelisahan tubuh. sedangkan kukkucca adalah penyesalan yang muncul dari mengomel pada masa lalu, kenangan atau imajinasi (Piya Tan. 2014.).

Validasi teoritis oleh panelis untuk validasi butir menggunakan Indeks Kecocokan Aiken berdasarkan hasil analisis ada 19 butir yang didroop. Hal tersebut dilakukan karena butir tersebut memiliki nilai $V<0,2$ yang berarti butir tersebut tidak valid berdasarkan penilaian 15 panelis. Berdasarkan penghitungan reliabilitas antarrater mengunakan rumus Hoyt nilai $r^{\wedge} 11: 0,779$ itu berarti instrumen temperamen (carita) yang dikembangkan memiliki keajegan.

Pada tahap pengujian empiris, proses pertama yang dilakukan yaitu dengan menyeleksi butir butir dengan pengujian daya beda. Seleksi butir menggunakan uji daya beda (daya diskriminasi) dilakukan untuk mengetahui sejauh mana item mampu membedakan antara individu atau kelompok individu yang memiliki dan tidak atribut yang diukur. Batasan pemilihan item adalah 0,3, namun sesuai pernyataan Azwar (2012: 83) batasan ini adalah konvensi yang artinya peneliti dapat menentukan batasan tersendiri disesuaikan dengan karakteristik penelitiannya. Batasan minimal daya diskriminasi item dalam penelitian ini yaitu sebesar $\geq 0.2$, hal 
ini dilakukan dengan pertimbangan bahwa butir yang dikembangkan tidak terlalu banyak, kemudian batasan tersebut dianggap wajar karena penelitian ini termasuk dalam bidang psikologi pendidikan keagamaan yang tidak mengharuskan batasan yang sangat ketat seperti pada penelitian di bidang kedokteran. Uji daya beda dalam penelitian ini dengan korelasi product moment Pearson yang kemudian dikoreksi dengan Corrected Item Total. Koreksi dengan Corrected Item Total dilakukan untuk menghindari overestimed. Sesuai pernyataan Azwar (2012: 83) formula koreksi terhadap efek spurious overlap menggunakan Corrected Item Total Correlation. Dari 80 butir yang dikembangkan sesuai dengan tabel 3 di atas ada 32 butir yang memiliki uji daya beda tidak memuaskan, butir tersebut didroop karena dianggap tidak mampu membedakan antara individu yang memiliki atribut yang diukur dengan yang tidak memiliki.

Pengujian validitas konstruk dalam penelitian ini menggunakan second order CFA. Hal tersebut dilakukan karena instrumen yang dikembangkan terdiri dari multidimensi, ini sesuai yang dinyatakan Latan (2013: 74) jika konstruk berbentuk multidimensi maka pengujiannya menggunakan second order CFA. Berdasarkan output second order CFA pertama kali terdapat Heywood cases. Untuk mengatasi hal tersebut dilakukan estimasi ulang setelah menetapkan variance error dengan nilai positif kecil dan hasilnya semua tanda "WARNING" hilang. Namun demikian sesuai dengan diagram second order CFA berdasarkan standardized solution seperti ada pada gambar 2 di atas, ada indikator yaitu F7 yang mempunyai nilai factor loading $<0,5$. Hal tersebut berarti indikator tersebut tidak valid dan harus didroop. Setelah indikator F7 dibuang dan memodifikasi model sesuai dengan modification indicies kemudian mengestimasi ulang dengan second order CFA berdasarkan tabel Goodnes of Fit Model pada tabel 4 diatas dan membandingkannya dengan cut of value dapat dinyakan bahwa model telah fit. Hal tersebut dapat dilihat pada tabel 4 diatas terdapat enam kriteria yang memenuhi standar dan mewakili ketiga kelompok kriteria yaitu: pada kelompok Abso- lute fit indicies yaitu nilai RMSEA 0,0093 yang berarti acceptabel fit. Pada kelompok Incremental fit indicies, yang memenuhi standar antara lain $\mathrm{NFI}, \mathrm{CFI}, \mathrm{IFI}$, dan RFI dan parsimony fit indicies. Dan pada kelompok parsimony fit indicies yaitu nilai AIC bernilai positif dan lebih kecil dibandingkan dengan sebelum dimodifikasi yang berarti memenuhi standar fit. Sesuai pernyataan Hair et al dalam Latan bahwa penggunaan 4-5 kriteria goodnes of fit sudah cukup memadai untuk menilai kelayakan suatu model.

Berdasarkan rekapitulasi dari nilai tvalue, factorloading, std error pada tabel 5 di atas dapat dinyatakan bahwa setelah dimodifikasi, seluruh indikator memiliki nilia factor loading $\geq 0,5$ yang berarti semua indikator yang dikembangkan adalah valid. Berdasar tabel 5 nampak pula bahwa semua hubungan konstruk dan indikatornya signifikan. Hal tersebut ditunjukan oleh nilai t-value (t-statistik) lebih besar dari 1,96. Seperti yang ditunjukan oleh indikator $\mathrm{A} 2, \mathrm{~A} 3, \mathrm{~A} 4, \mathrm{~A} 5, \mathrm{~A} 6$, dan $A 7$, itu berarti bahwa masing-masing indikator adalah pembentuk konstruk dari 'RC' (Ragacarita) demikian pula dengan dimensi lainnya.

Uji reabilitas butir dilakukan dengan melihat nilai squared multiple correlation pada output lisrel. Berdasarkan tabel 5 terlihat bahwa pada dimensi RC indikator A5 memiliki nilai reabilitas paling tinggi dibanding indikator lainnya yaitu 0,86 . Hal tersebut berarti bahwa dimensi RC berkontribusi terhadap varaians A5 sebesar $86 \%$ sedangkan sisanya $14 \%$ djelaskan oleh variabel lainnya yang tidak termasuk dalam model. Penjelasan ini juga berlaku bagi dimensi lainnya. Kontribusi konstruk laten temperamen (carita) terhadap dimensi ragacarita $(\mathrm{RC})$, dosacarita (DC), mohacarita $(\mathrm{MC})$, saddhacarita (SC), buddhicarita (BC), dan vitakacarita (VC) berturut-turut sebesar $99 \%, 99 \%, 98 \%, 100 \%, 99 \%$, dan $100 \%$. Hal tersebut dapat dilihat dari nilai $\mathrm{R}^{\wedge} 2$, nampak bahwa dimensi yang paling kurang reliabel adalah mohacarita (MC) karena memiliki nilai yang paling kecil $(0,98)$.

Pengujian reliabilitas konsistensi internal dalam penelitian ini dilakukan berdasarkan penghitungan nilai Construct Reliability (CR) dan Variance Extraced (VE) dengan meng- 
gunakan factor loading dan error. Semakin besar nilai CR dan VE menunjukan bahwa indikator penyusun bagi suatu konstruk laten merupakan indikator yang handal dalam mengukur konstruk laten tersebut. Berdasarkan tabel 6 di atas terlihat bahwa nilai CR dan VE berdasarkan perhitungan melebihi nilai cut off (CR $\geq 0,7$ dan $V E \geq 0,5)$, dapat disimpulkan bahwa seluruh indikator yang berjumlah 39 dinyatakan reliabel. Demikian juga dengan dimensi ragacarita (RC), dosacarita (DC), mohacarita (MC), saddhacarita (SC), buddhicarita (BC), dan vitakacarita (VC) semuanya reliabel. Jadi ada 39 indikator dari isntrumen yang dikembangkan yang memenuhi kriteria valid dan reliabel.

\section{Kesimpulan}

Berdasarkan hasil pengujian secara teoritis dan empiris dapat disimpulkan bahwa instrumen temperamen (carita) dalam perspektif buddhis berdasarkan Kitab Visuddhimagga maka terdapat enam temperamen (carita) yaitu: Ragacarita, Dosacarita, Mohacarita, Saddhacarita, Budicarita, dan Vittakacaritayang terdiri dari 39 indikator. Validitas instrumen temperamen (carita) berdasar nilai factor loading pada pengujian empiris berkisar antara 0,99 - 1 yang berarti instrumen temperamen (carita) yang dikembangkan valid. Reliabilitas instrumen temperamen (carita) berdasarkan nilai Construct Reliability (CR) sebesar 0,99 dan berdasar Varian Extraced (VE) sebesar 0,99 yang berarti instrumen yang dikembangkan adalah reliabel

Instrumen ini dapat digunakan untuk menentukan jenis temperamen dari responden yang mengisi kuesioner. Instrumen yang dikembangkan dikhususkan untuk mahasiswa buddhis, namun demikian dengan sedikit modifikasi pernyataan/pertanyaan yang ada dalam kuesioner, instrumen ini dapat digunakan untuk umat Buddha pada umumnya sehingga mereka dapat mengetahui jenis temperamen mereka. Dengan mengetahui jenis temperamennya maka ia akan dapat memilih objek meditasi yang sesuai dengan karakter dirinya sehingga ia dapat mencapai keberhasilan. Instrumen ini juga dapat digu- nakan oleh masyarakat pada umumnya untuk menentukan jenis tempermen. Dengan mengetahui jenis temperamennya maka seseorang akan dapat mengeliminasi karakter negatif yang sering muncul dan dapat mengembangkan karakter positif yang ada dalam dirinya, bahkan dengan mengetahui jenis temperamennya maka ia juga dapat memilih jenis makanan, gaya pakaian, dan tempat tinggal yang sesuai temperamen.

\section{Daftar Pustaka}

Abdullah. (2007). Pemodelan Persamaan Struktural dan Paket Program Lisrel. Jakarta: Universitas Prof DR Moestopo (BERAGAMA).

Angleitner, Alois \& Rainer Riemann. (1991). What Can We Learn from the Discussion of Personality Questionnaires for the Construction of Temperament Inventories?, Exporation in Temperament International Perspectives on Theory and Measurement. Ed Jan Strelau \& Alois Angleitner. New York: Springer Science + Busines Media.

Azwar, Saifuddin. (2012) Penyusunan Skala Psikologis. Yogyakarta: Pustaka Pelajar.

Azwar, Saifuddin. (2013). Reliabilitas dan Validitas. Yogyakarta: Pustaka

Bodhi. (2012). Abhidhammattha Sangaha a Comprehensive Manual of Abhidhamma. Washington: Pariyatti.

Buddhaghosa, Bhadantacariya.(1996). Jalan Kesucian 2 (Visuddhi Magga). Terjemahan ke dalam Bahasa Inggris oleh: Nanamoli, terjemahan ke dalam Bahasa Indonesia oleh: Team Penterjemah Jalan Kesucian (Koordiator Lindawati T.) Bali: PT. Indografika Utama.

Davids, Rhys \& William Stede. "The Pali Text Society's Pali-English Dictionary". www.dharma.org.ru

Latan, Hengky. (2013). Struktural Equation Modeling Konsep dan Aplikasi Menggunakan Program LISREL 8.80. Bandung: Alfabeta. 
Mingun. (2009). The Great Chronicle of Buddhas. Jakarta: Ehipassiko Foundations \& Girimangala Publications.

Naga, Dali Santun (2013). Teori Skor Pada Pengukuran Mental. Jakarta: PT Nagarani Citrayasa.

Nànamoli. (2011). Visuddhimagga The Path of Purification. Kandy Sri Lanka: Buddhist Publication Society.

Piya Tan. (2014). Uddhacca, kukkucca. http://dharmafarer.org/wordpress/ wp-content/uploads/2010/02/32.7Uddhaccakukkucca-piya.pdf. diakses 20 Februari 2016).

Priyatno, Duwi. (2009). 5 Jam Belajar Olah Data dengan SPSS 17. Yogyakarta: ANDI.

Soeprijanto. (2010). Pengukuran Kinerja Guru Praktik Kejuruan Konsep dan Teknik Pengembangan Instrumen. Jakarta: CV Tursina.
Pengembangan Instrumen. Jakarta: CV Tursina.

Supranto, J. (2010). Analisis Multivariat Arti dan Interpretasi. Jakarta: Rineka Cipta.

Uno, Hamzah B., Herminanto Sofyan, dan I Made Candiasa. (2001). Pengembangan Instrumen Untuk Penelitian. Jakarta: Delima Press.

Upatissa. (1961). The Path of Freedom (Vimuttimagga). Ceylon: The Saman Press.

Widhiarso, Wahyu. (2012). "Koefisien Reliabilitas Untuk Pengukuran Multidimensi," https://www.elisa1. ugm.ac.id.widhiarso. (diakses 29 Januari 2015).

Yamin, Sofyan. (2014). Seri Buku Stattistik: Structural Equation Modeling Untuk Pemula Rahaisa Olah Data Lisrel. Jakarta: Mitra Vacana Media 